\title{
A METHOD FOR THE ESTIMATION OF SERUM HAPTOGLOBINS
}

\author{
Corporal W. E. G. HOWARD, A.I.M.L.T., S.R.M.L.T., R.A.M.C. \\ Department of Pathology, Royal Army Medical College
}

\section{Introduction}

An attempt has been made to devise a simple and reproducible technique for the estimation of the haemoglobin-combining capacity of serum which could be easily carried out in laboratories where the test is performed only infrequently.

The technique utilises the well-documented property of some serum components, (mainly the alpha-2 fractions) of combining both in vivo and vitro with free haemoglobin (Hall, 1964, Row, 1961, and Smith 1965). This effect may be useful in the investigation of the nature and time of intravascular haemolysis.

When known concentrations of haemoglobin are added to serum and the resultant mixture electrophoresed at $\mathrm{pH} 7$ the haptoglobin/haemoglobin complex is attracted towards the anode, while free haemoglobin migrates to the cathode by endosmosis. The dilution at which free haemoglobin separates from the mixture may thus be taken as the haemoglobin-combining power of the serum and expressed as $\mathrm{mg}$ per $100 \mathrm{ml}$ of serum.

\section{Electrophoresis bath}

\section{Materials}

No suitable bath was available; consequently one was constructed in the laboratory at a cost of less than ten shillings (Fig 1). It was made from a plastic partitioned

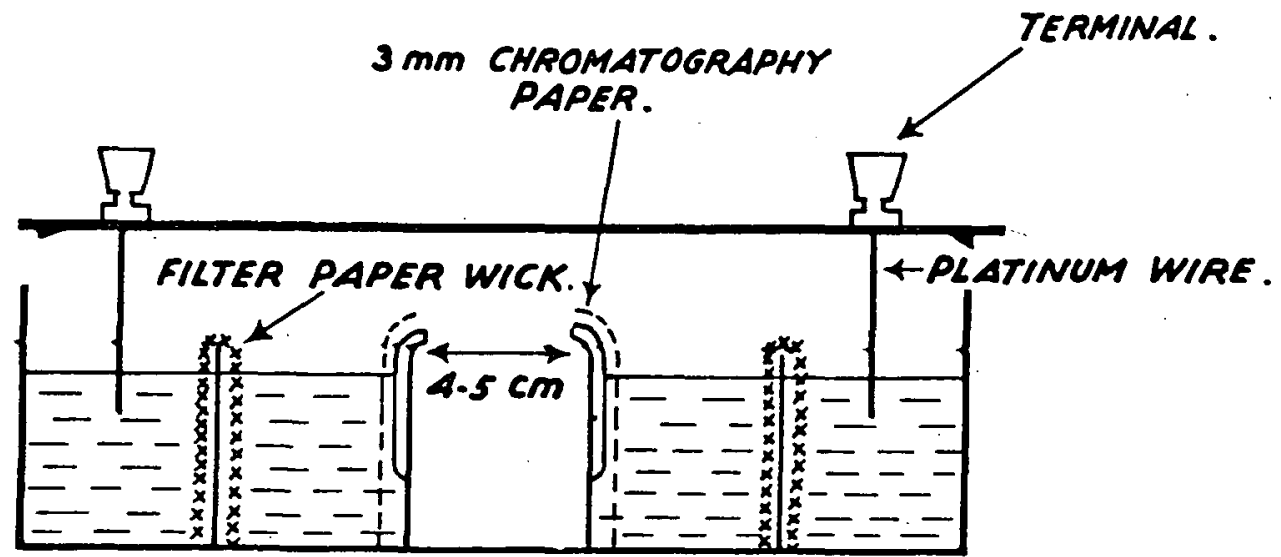

Fig. 1-Diagram of electrophoresis bath.

nail/screw container, $18 \times 12 \times 4 \mathrm{~cm}$. This was originally divided internally into ten compartments and fitted with a lid. The internal partitions were utilised by removing the longitudinal former and reducing the transverse formers in height by a half an inch. Curved supports of perspex were bonded to the inner formers using chloroform as a 
solvent. The electrodes were constructed from platinium wire connected to terminals which projected through the lid.

Power source

Any power source capable of delivering a constant 6-8 mA was found suitable.

\section{Supporting media}

Oxid cellulose acetate strips $20 \times 5 \mathrm{~cm}$, reduced to $10 \times 5 \mathrm{~cm}$ were used.

\section{Buffer}

Of the several buffers tried, "Sorenson's " phosphate buffer (Varley, 1962) pH 7 and molarity of $M / 15$ was found most satisfactory. Approximately $200 \mathrm{ml}$ were required to fill the bath and soak the supporting media. The working life of the buffer was extended by reversing the current after each run.

\section{Stock haemolysate solution}

Cells from a freshly collected blood sample were well washed with physiological saline and adjusted to a haemoglobin content of $10 \mathrm{~g}$ per $100 \mathrm{ml}$. From this a standard haemolysate equivalent to $1,000 \mathrm{mg}$ per $100 \mathrm{ml}$ was made. When converted to carboxyhaemoglobin with coal gas this haemolysate was found to be stable for several months at minus $20^{\circ} \mathrm{C}$.

\section{Working haemolysate solution}

Using distilled water as a diluent, working solutions were prepared from the stock solution at the following concentrations:-20,40,60,80,100,120,140,160, and $180 \mathrm{mg}$ of haemoglobin per $100 \mathrm{ml}$.

\section{Stain}

Orthotolidine was found to be most suitable for demonstrating the small concentrations of haemoglobin on the strip. The stain was prepared immediately before use as follows: -4 per cent orthotolidine in ethanol $10 \mathrm{ml}$ : glacial acetic acid (AR) $10 \mathrm{ml}$ : distilled water $10 \mathrm{ml}$ : hydrogen peroxide ( 20 vols) $3 \mathrm{ml}$. (When higher concentrations of hydrogen peroxide were used it was found the stained areas faded much more rapidly.

\section{Sample}

A fresh sample of serum was obtained. This may be stored for two days at $4^{\circ} \mathrm{C}$. It is important that no haemolysis is caused during the taking or separation of the serum.

\section{Preparation of bath}

\section{Method}

The bath was charged with buffer after the filter paper wicks and beds had been damped and put in place. The beds must be evenly moistened and the buffer level in all compartments equal.

\section{Serum/haemolysate mixture}

To prepare the serum haemolysate mixture, equal volumes of serum and working 
haemolysate were mixed. The volumes used are immaterial but $0.1 \mathrm{ml}$ amounts delivered by a "Sanz" pipette were found satisfactory.

\section{Application of serum/haemolysate mixtures}

A cellulose acetate strip was marked down the mid-line with pencil, soaked in buffer, blotted, and placed with its width across the supports. The mixtures were applied without delay (Fig 2) using a fine capillary pipette capable of delivering about $0.001 \mathrm{ml}$.

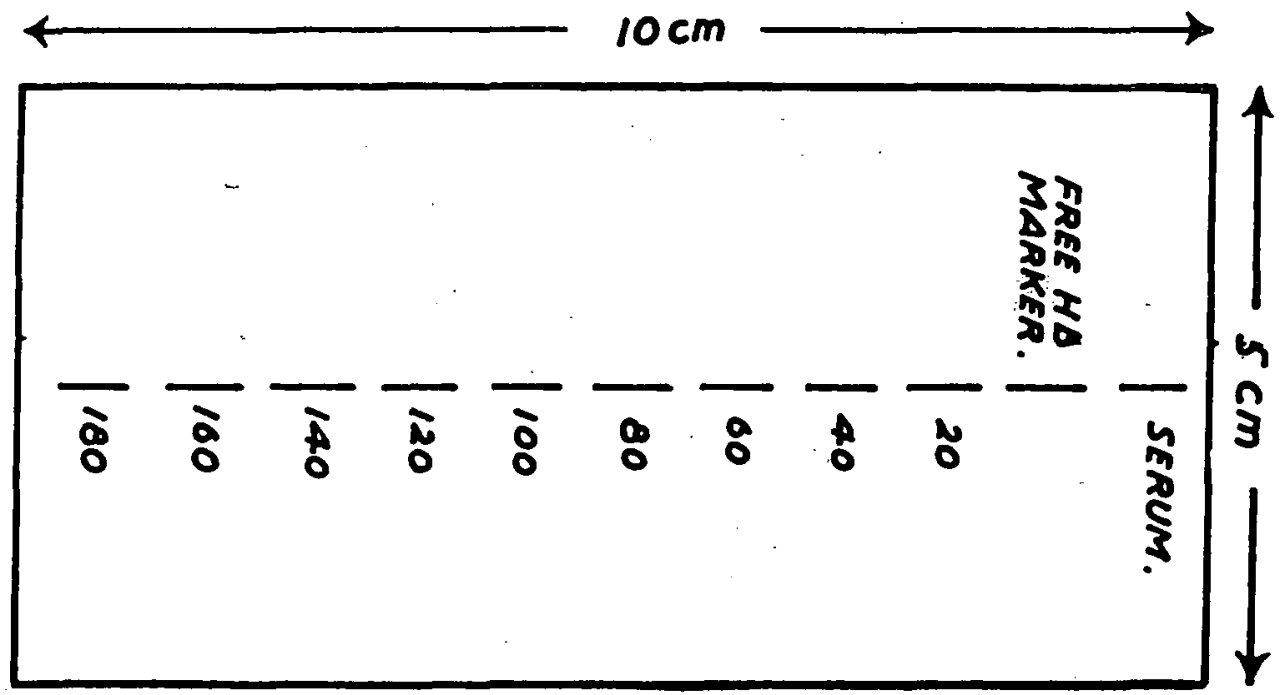

Fig. 2-Diagram indicating the position of haemoglobin/serum mixtures on strip

A serum blank and free haemoglobin marker $(10 \mathrm{mg}$ per $100 \mathrm{ml})$ were included. The lid was firmly placed in position and a current of 6-8 $\mathrm{mA}$ applied for 20 minutes. The strip was removed and immediately placed in the stain; areas of haemoglobin appeared dark blue.

\section{Discussion}

By the method described the point at which the serum haptoglobins became saturated with haemoglobin was shown when free haemoglobin separated from the haemoglobin/ haptoglobin complex. Haemolytic episodes were clearly demonstrated in a patient suffering from introvascular haemolysis and normal sera showed a drop in binding capacity equivalent to amounts of added haemoglobin. The normal range by this method was found to be between 40 and $180 \mathrm{mg}$ of haemoglobin bound per $100 \mathrm{ml}$ of serum and the method gave reproducible results, even in the hands of different operators.

\section{Summary}

A simple electrophoretic technique for the estimation of hermoglobin-combining capacity is described.

\section{REFERENCES}

HALL, R., (1964). J. med. Lab. Technol. 21, 64.

Row, P. S. (1961). J. Clin. path., 6, 205.

SMITH, I. (1965). "Chromotographic and Electrophoretic Techniques" Vol. 2. Heinemann, London.

VARLEY, R. (1962) "Practical Clinical Biochemistry". Heinemann, London. 